\title{
The NF-кB Activating Pathways in Multiple Myeloma
}

\author{
Payel Roy ${ }^{\dagger}$, Uday Aditya Sarkar and Soumen Basak* \\ Systems Immunology Laboratory, National Institute of Immunology, Aruna Asaf Ali Marg, \\ New Delhi 110067, India; payelroy87@nii.ac.in (P.R.); udayaditya2992@nii.ac.in (U.A.S.) \\ * Correspondence: sobasak@nii.ac.in \\ + Present Address: La Jolla Institute of Allergy and Immunology, La Jolla, CA 92037, USA.
}

Received: 12 March 2018; Accepted: 14 May 2018; Published: 16 May 2018

\begin{abstract}
Multiple myeloma(MM), an incurable plasma cell cancer, represents the second most prevalent hematological malignancy. Deregulated activity of the nuclear factor kappaB (NF- $\mathrm{KB}$ ) family of transcription factors has been implicated in the pathogenesis of multiple myeloma. Tumor microenvironment-derived cytokines and cancer-associated genetic mutations signal through the canonical as well as the non-canonical arms to activate the NF- $\kappa B$ system in myeloma cells. In fact, frequent engagement of both the NF- $\mathrm{kB}$ pathways constitutes a distinguishing characteristic of myeloma. In turn, NF- $\mathrm{kB}$ signaling promotes proliferation, survival and drug-resistance of myeloma cells. In this review article, we catalog NF- $\mathrm{kB}$ activating genetic mutations and microenvironmental cues associated with multiple myeloma. We then describe how the individual canonical and non-canonical pathways transduce signals and contribute towards NF- $\mathrm{kB}$-driven gene-expressions in healthy and malignant cells. Furthermore, we discuss signaling crosstalk between concomitantly triggered NF- $\mathrm{kB}$ pathways, and its plausible implication for anomalous NF- $k B$ activation and NF- $k B$ driven pro-survival gene-expressions in multiple myeloma. Finally, we propose that mechanistic understanding of NF- $\mathrm{kB}$ deregulations may provide for improved therapeutic and prognostic tools in multiple myeloma.
\end{abstract}

Keywords: NF-kB; multiple myeloma; canonical; non-canonical; mutations; microenvironment; cytokines; crosstalk; gene-expressions

\section{General Introduction}

Heterogeneous cancer-associated mutations often influence the interaction of malignant cells with their microenvironment that modifies therapeutic outcomes. Therefore, an understanding of the molecular mechanism underlying the coordinated functioning of genetic mutations and microenvironmental cues may have significance for the effective management of neoplastic diseases. Within the tumor microenvironment, immune cells as well as stromal cells secrete a diverse array of pro-inflammatory cytokines, which activate key pro-survival signaling pathways in malignant cells. Of particular importance is the NF- $\mathrm{kB}$ system, which forms a major link between cancer and inflammation. Interestingly, sequencing of cancer genomes revealed recurrent gain-of-function mutations in genes encoding key positive regulators of NF- $\mathrm{kB}$ signaling and inactivating genetic aberrations in negative regulators of this pathway. Multiple myeloma (MM), a plasma cell malignancy, provides one of the best examples where a number of mutations have been mapped onto the NF- $\mathrm{KB}$ pathway. In addition, microenvironment-derived signals were also shown to modulate NF-kB-dependent gene expressions in myeloma cells. Here, we briefly review multiple myeloma and the NF- $\mathrm{KB}$ signaling system. We then discuss the NF- $\mathrm{kB}$-activating genetic lesions associated with MM and the role of the tumor microenvironment in reinforcing NF- $\kappa B$ signaling in cancerous cells. Finally, we elaborate interdependent regulations of NF-kB-activating pathways in MM. 


\section{Multiple Myeloma-Epidemiology and Aetiology}

Multiple myeloma is the second most widespread hematologic malignancy after non-Hodgkin lymphoma, with a global estimate of 103,826 new cases and 72,453 mortalities annually [1]. The disease is more prevalent in men than in women, and the median age at diagnosis is 66 years [2]. The disease incidence also varies with ethnicity, being more prevalent among Caucasians than in Asians [1]. The American Cancer Society estimates that about 30,770 individuals (16,400 men and 14,370 women) will be diagnosed with this disease in the USA in 2018 (https:/ / cancerstatisticscenter.cancer.org/\#! /cancer-site/Myeloma; accessed on 10 March 2018). Indeed, it has been found that the incidence and the mortality rate are significantly higher in African Americans as compared to their Caucasian counterparts [3]. Various studies estimate that the incidence of MM in India is around 1.2-1.8 per 100,000 individuals.

$\mathrm{MM}$ is characterized by the clonal proliferation of cancerous plasma cells (PCs) in the bone marrow microenvironment and an associated increase in the level of monoclonal (M) protein in blood and serum [4]. Myeloma cells are characterized by high rates of somatic hypermutation of immunoglobulin (Ig) genes and isotype class switching, but differ from healthy PCs with respect to the abundance of certain cell surface molecules, including CD138 and CD38 [5,6]. In most cases, MM develops from monoclonal gammopathy of undetermined significance (MGUS) and smouldering MM (SMM) (Figure 1), conditions that involve high levels of M-protein and bone marrow (BM) plasmacytosis [7]. Clinical manifestations of MM include lytic bone lesions, hypercalcemia, cytopenia, renal dysfunction, hyperviscosity and peripheral neuropathy [8].

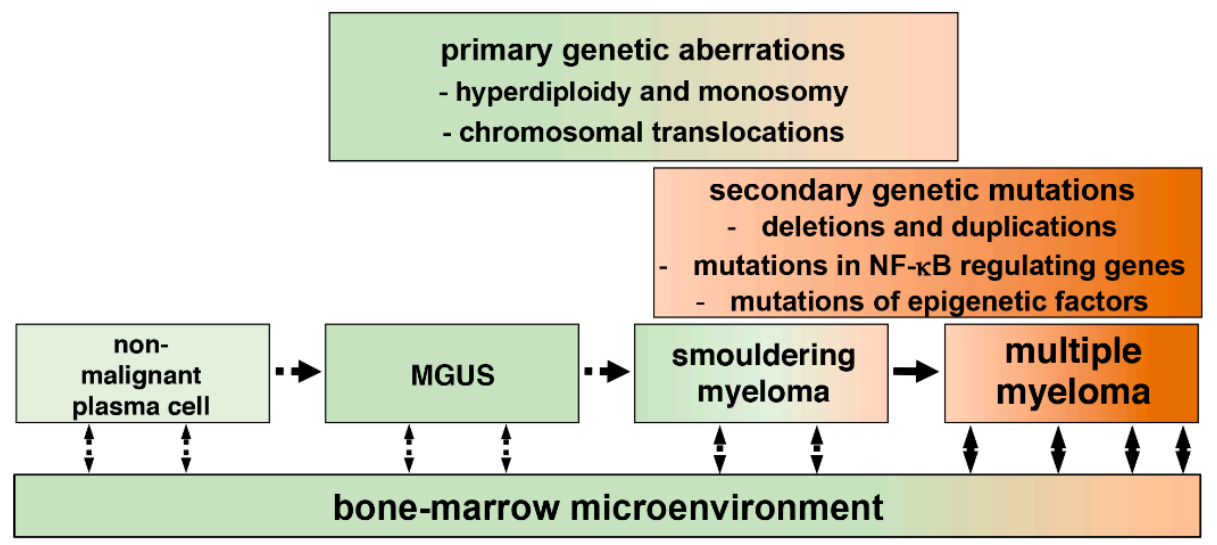

Figure 1. Development of multiple myeloma (MM) from plasma cells. Progression of MM from post-germinal center plasma cells to symptomatic myeloma occurs through intermediate MGUS (monoclonal gammopathy of undetermined significance), and SMM (smouldering MM) stages. Plasma cells associated with MGUS and SMM may display chromosomal abnormalities, which trigger cellular transformation. Cancerous plasma cells acquire additional, secondary genetic mutations, which support tumor growth by activating key signaling pathways in malignant cells. Finally, cell-cell communications, which involve physical interactions between cancerous cells and cancer-associated stromal cells, and secretion of cytokines and other soluble factors, promote survival and proliferation of myeloma cells within the bone marrow microenvironment.

Therapeutic intervention for MM currently involves six categories of medication-(1) immunomodulatory drugs (IMiDs) such as lenalidomide and pomalidomide; (2) proteasome inhibitors (PIs) such as bortezomib, carfilzomib, and ixazomib; (3) histone deacetylase inhibitors such as panobinostat; (4) monoclonal antibodies (MAbs) such as daratumumab and elotuzumab; (5) DNA alkylating agents; and (6) glucocorticosteroids [9]. Recent advancement in the management of the disease led to a substantial improvement in the 5-year survival rate in MM. The 5-year relative survival percent reported in the SEER database of the National Cancer Institute, USA steadily improved 
from $24.6 \%$ in between 1975-1977 to 52.4\% in between 2008-2014 (https: / seer.cancer.gov / csr / 1975 2015/browse_csr.php?sectionSEL=18\&pageSEL=sect_18_table.08.html; accessed on 14 May 2018). The disease, however, remains incurable because of widespread drug-resistance and relapse in most patients.

Although it is difficult to pinpoint the exact trigger of MM, karyotyping and DNA sequencing studies involving patient-derived cells or MMCLs identified several genomic translocations and mutations (Table 1 and Figure 1). The frequency and extent of these genetic aberrations were substantially augmented in individuals with advanced-stage disease or poor prognosis and in those with refractory MM unresponsive to therapy [10-13]. Nearly half of the MM tumors are hyperdiploid, characterized by trisomies of chromosomes 3, 5, 7, 9, 11, 15, 19 and 21 [14]. The non-hyperdiploid $\mathrm{MM}$ is associated with chromosomal translocations involving the immunoglobulin heavy-chain $(\mathrm{IgH})$ locus and the loci encoding MMSET, FGFR3, CCND3 (cyclin D3), CCND1 (cyclin D1), MAF (c-Maf) or MAFB [15-20]. Moreover, duplications involving chromosome 1 and deletions affecting several other chromosomal arms have been associated with the onset of the disease [21-23]. Mutational events secondary to oncogenic transformation have also been reported in MM [24]. For example, frequent mutations have been observed in RAS-encoding NRAS and KRAS genes that triggered aberrant MAPK activity [25]. In addition, secondary mutations were mapped onto genes implicated in NF- $\mathrm{KB}$ regulations (discussed later), CDKN2C that encodes cyclin-dependent kinase inhibitor 2C [26], TP53 expressing the tumor suppressor p53 [27] and MYC that codes for the proto-oncogene cMyc [28]. Disease progression is also influenced by physical or cytokine-mediated interactions between myeloma cells and the bone-marrow stromal cells. These cell-to-cell communications further inform the proliferative and anti-apoptotic program by modulating the NF- $\mathrm{kB}$ activity in myeloma cells.

The complex mutational landscape, which produces bioclinical heterogeneity, presents a significant challenge in the management of multiple myeloma. Risk-prediction based on traditional biomarkers measured using solely protein analysis and conventional cytologic assays often do not match with the actual patient outcomes and exhibit poor correlation with the minimal residual disease (MRD). Cutting-edge next-generation sequencing (NGS) technology has now made it possible to acquire a more comprehensive view of genomic alterations in MM. NGS not only offers genome-scale data but can also detect very low-frequency mutations [29]. Not surprisingly, NGS-based methods substantially improved the sensitivity of MRD detection in MM [30]. Furthermore, NGS provides for reliable measurement involving both bone-marrow samples and blood biopsies, enabling non-invasive diagnosis of MM. In fact, these high-throughput sequencing technologies helped to define the mutational landscape of bone-marrow resident as well as circulating myeloma cells at single-cell resolution [31]. As discussed later, NGS-based studies were also instrumental in charting NF- $\mathrm{kB}$ deregulating mutations in MM. In this article, we have focused on NF- $\mathrm{KB}$ deregulations in MM; for a more comprehensive description of $\mathrm{MM}$ and the underlying genetic as well as cell-signaling anomalies, please see $[4,32]$.

Table 1. Genetic abnormalities in multiple myeloma (MM).

\begin{tabular}{|c|c|c|c|}
\hline Genetic Abnormalities & Genes or Chromosomes Affected & Comments & References \\
\hline Hyperdiploidy & chromosomes $3,5,7,9,11,15,19,21$ & $\begin{array}{l}\text { Functional role in the pathogenesis of MM remains } \\
\text { elusive. }\end{array}$ & {$[12,14]$} \\
\hline Monosomy & chromosome 13 & Functional role of remains unclear. & [11] \\
\hline \multirow{2}{*}{$\begin{array}{l}\text { Frequent IGH } \\
\text { translocations }\end{array}$} & $\begin{array}{l}\mathrm{t}(11 ; 14)(\mathrm{q} 13 ; \mathrm{q} 32) C C N D 1 \\
\mathrm{t}(4 ; 14)(\mathrm{p} 16 ; \mathrm{q} 32) \text { FGFR3 }\end{array}$ & $\begin{array}{l}\text { Upregulate the expression of oncogenes encoding } \\
\text { cyclin D1 and fibroblast growth factor receptor } 3 \text {. }\end{array}$ & {$[15,16]$} \\
\hline & $\mathrm{t}(4 ; 14)(\mathrm{p} 16 ; \mathrm{q} 32) M M S E T / W H S C 1$ & $\begin{array}{l}\text { Upregulate the expression of } M M S E T \text {, which } \\
\text { methylates chromatin-associated proteins and } \\
\text { modulates their functions. }\end{array}$ & [17] \\
\hline
\end{tabular}


Table 1. Cont

\begin{tabular}{|c|c|c|c|}
\hline Genetic Abnormalities & Genes or Chromosomes Affected & Comments & References \\
\hline $\begin{array}{l}\text { Relatively rare } \\
\text { translocations }\end{array}$ & $\begin{array}{c}\mathrm{t}(14 ; 16)(\mathrm{q} 32 ; \mathrm{q} 23) M A F \\
\mathrm{t}(14 ; 20)(\mathrm{q} 32 ; \mathrm{q} 11) M A F B \\
\mathrm{t}(6 ; 14)(\mathrm{p} 21 ; \mathrm{q} 32) C C N D 3\end{array}$ & $\begin{array}{l}\text { These chromosomal translocations cause } \\
\text { deregulated expressions of cell cycle regulators, } \\
\text { including cyclin D2 and cyclin D3. }\end{array}$ & [18-20] \\
\hline Duplication & chromosome 1 (1q) & $\begin{array}{l}\text { Increased incidences in advanced MM, functional } \\
\text { roles are unclear. }\end{array}$ & [23] \\
\hline \multirow{4}{*}{ Deletions } & $1 p, 6 q, 8 p, 12 p, 14 q, 16 q, 17 p, 20 p$ & Functional role remains unclear. & {$[21,22]$} \\
\hline & $\begin{array}{c}\text { BIRC2 } \\
\text { BIRC3 } \\
\text { TRAF3 } \\
\text { CYLD }\end{array}$ & $\begin{array}{l}\text { Frequent homozygous deletions, which disrupt the } \\
\text { function of various inhibitors of the NF- } \mathrm{kB} \text { system. }\end{array}$ & {$[33,34]$} \\
\hline & TNFAIP3 & $\begin{array}{l}\text { Heterozygous deletions, which inactivate the } \\
\text { inhibitor of IKK, A20. }\end{array}$ & [35] \\
\hline & CDKN2C & $\begin{array}{l}\text { Abrogate the function of the tumor suppressor } \\
\text { protein cyclin-dependent kinase inhibitor } 2 \mathrm{C} \text {. }\end{array}$ & [26] \\
\hline \multirow[t]{2}{*}{ Gene mutations } & $\begin{array}{l}\text { NRAS } \\
\text { KRAS } \\
B R A F\end{array}$ & $\begin{array}{l}\text { Gain-of-function mutations in NRAS and KRAS } \\
\text { trigger aberrant MAPK activity and are associated } \\
\text { with the progression of MM, mutations in the } \\
B R A F \text { oncogene promote myeloma growth. }\end{array}$ & [25] \\
\hline & TP53 & $\begin{array}{l}\text { Abrogate the expression of p53 tumor suppressor } \\
\text { in advanced MM. }\end{array}$ & [27] \\
\hline $\begin{array}{l}8 \mathrm{q} 24 \text { locus } \\
\text { rearrangements }\end{array}$ & $M Y C$ & Upregulate the expression of the $M Y C$ oncogene. & [28] \\
\hline
\end{tabular}

\section{The NF- $k$ B Signaling System}

The nuclear factor kappa B (NF-kB) system functions in a wide variety of cells and coordinates innate and adaptive immune responses. Not surprisingly therefore, deregulated NF- $\mathrm{KB}$ activities have been implicated in several human ailments, including hematologic cancers [36,37]. The NF- $\mathrm{kB}$ family consists of five structurally related monomeric subunits: RelA (also called p65), RelB, c-Rel, p50 (encoded by NFKB1 and produced as a precursor protein p105) and p52 (encoded by NFKB2 and produced as a precursor p100). Combinatorial association of the mature subunits generate 15 possible homo- or heterodimeric transcription factors, with the most prevalent being the RelA:p50 and the RelB:p52 dimers. The NF- $\mathrm{kB}$ proteins possess a conserved Rel homology region (RHR) in their $\mathrm{N}$-termini that contains the domains for dimerization and DNA binding as well as a nuclear localization sequence (NLS). NF- $\kappa B$ dimers recognize a broad consensus DNA sequence known as the kB motif, which is represented as: 5'-GGRN(W)YYCC-3' (where $\mathrm{R}$ denotes A or G; N denotes A, C, G or T; $\mathrm{W}$ denotes an $\mathrm{A}$ or T; $\mathrm{Y}$ denotes $\mathrm{T}$ or $\mathrm{C}$ ) [38]. In resting cells, NF-kB factors are held inactive in the cytoplasm by inhibitor proteins. Extracellular stimuli trigger the canonical (also known as classical) or the non-canonical (also known as alternative) NF- $\mathrm{kB}$ pathway to induce translocation of NF- $\mathrm{kB}$ dimers into the nucleus, where they mediate the expression of hundreds of immune and stress response genes as well as immune-differentiating and pro-survival factors.

\section{The Canonical NF- $\kappa$ B Activation Pathway}

Activation of canonical NF- $\mathrm{kB}$ signaling: inhibitory I $\mathrm{kB}$ proteins, including the major isoform $\mathrm{I} \kappa \mathrm{B} \alpha$ as well as I $\mathrm{I} B \beta$ and $\mathrm{I} \kappa \mathrm{B} \varepsilon$, sequester pre-existing NF- $\kappa B$ dimers in the cytoplasm of unstimulated cells [39]. Signals emanating from cytokine receptors such as tumor necrosis factor receptor-1 (TNFR1), pathogen-sensing receptors such as Toll-like receptors (TLRs), and B- or T-cell antigen receptor (BCR or TCR) engage the canonical NF- $\kappa B$ pathway to activate NF- $k B$ dimers from the I $k B$-inhibited complexes (Figure 2A). Central to this pathway is the trimeric IкB kinase (IKK) complex, which is comprised of two catalytic subunits IKK1 (also known as IKK $\alpha$ ) and IKK2 (also known as IKK $\beta$ ) and a regulatory subunit NEMO (also known as IKK $\gamma$ ). However, the enzymatic activity of IKK2, and not IKK1, was found to be essential for triggering of the canonical pathway. Intracellular adaptor proteins belonging to the receptor-interacting serine/threonine-protein (RIP) and TNF receptor-associated factor (TRAF) families promote signal-induced activation of TGF $\beta$ activated kinase-1 (TAK1), which in 
turn phosphorylates and activates IKK2. In particular, K63-linked polyubiquitination of TRAF2 and TRAF6 as well as NEMO nucleates the assembly of a receptor-proximal complex, which coordinates the activation of upstream kinases of the canonical NF-кB pathway [40]. Indeed, deubiquitinating enzymes such as CYLD and A20 function as important negative regulators of NF- $\mathrm{B}$ signaling. The activated IKK complex, in turn, phosphorylates $I \kappa B \alpha, I \kappa B \beta$ and $I \kappa B \varepsilon$ that induce K48-linked polyubiquitination and proteasomal degradation of these classical I $\kappa$ Bs, and consequent release of the bound NF- $\kappa B$ dimers into the nucleus.

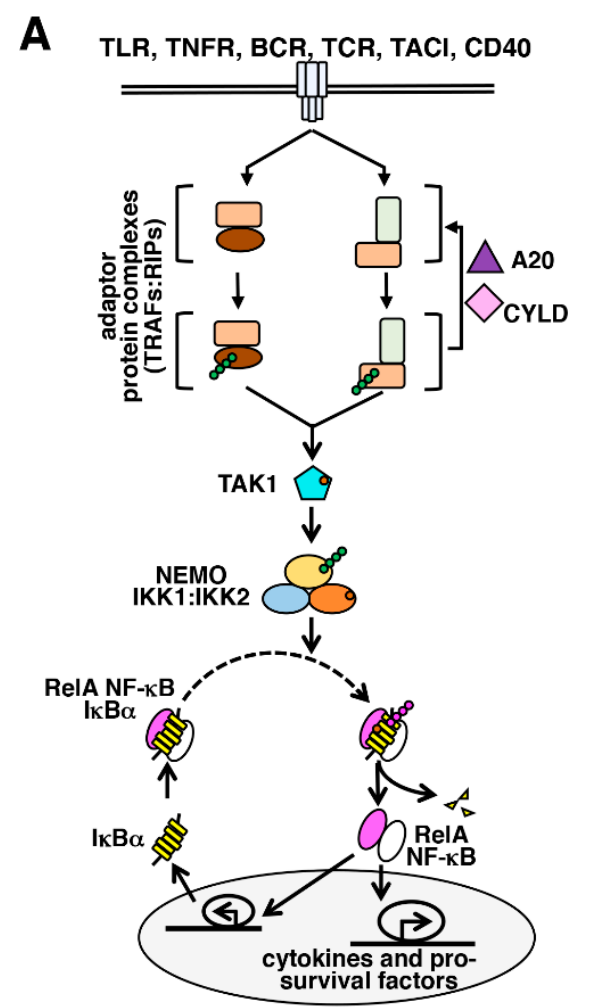

The canonical NF-кB activating pathway

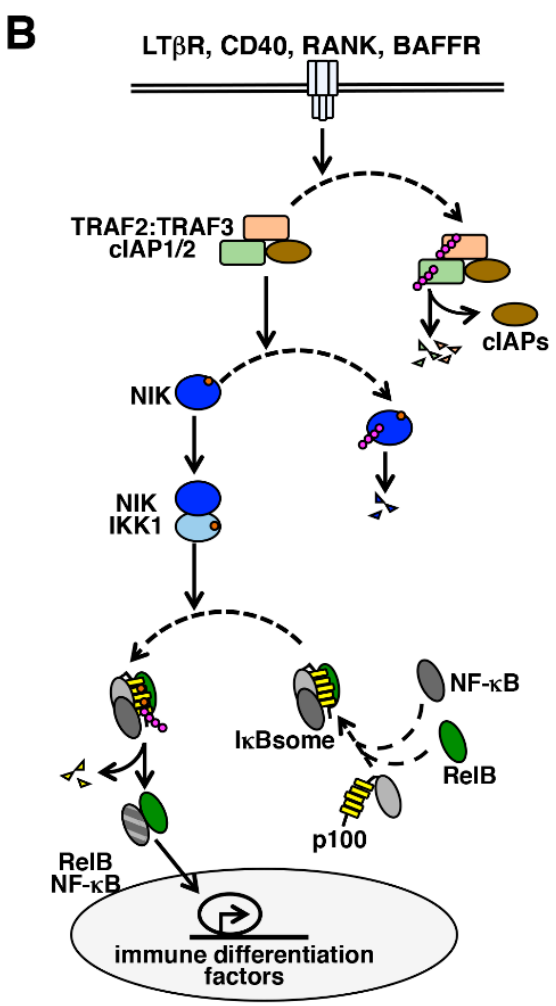

The non-canonical NF-kB activating pathway

Figure 2. NF- $\kappa B$ activating pathways. The NF- $k B$ system consists of (A) the canonical and (B) the non-canonical pathways. In general, immune-activating cues activate the canonical pathway, which stimulates the synthesis of pro-inflammatory and pro-survival factors involving the RelA NF- $\kappa$ B activity; and non-canonical signaling triggers RelB NF- $\kappa$ B activation during immune differentiation.

Target genes of the canonical NF-кB pathway: in most cell-types, canonical signaling activates RelA:p50 and c-Rel:p50 heterodimers. Once in the nucleus, these NF- $\kappa$ B heterodimers induce the transcription of an array of genes (see http:/ / www.bu.edu/nf-kb/ for a complete list). Importantly, $\mathrm{I} \kappa \mathrm{B} \alpha$ itself is encoded by an NF- $\kappa \mathrm{B}$ target gene; NF- $\kappa \mathrm{B}-$ dependent re-synthesis of I $\mathrm{B} \alpha$ constitutes a negative feedback loop that entails sequestration and nuclear export of NF- $\kappa$ B dimers by $\mathrm{I} \kappa \mathrm{B} \alpha$ and post-induction attenuation of the canonical NF- $\mathrm{B}$ response. Indeed, coordinated degradation and re-synthesis of classical I $\kappa$ Bs allow a tight control over the amplitude and the duration of the NF- $\kappa B$ activity induced in the canonical pathway [41]. There are several other review articles, including that of Mitchell et al. [41], that provide further details of the regulatory mechanisms underlying the activation and post-induction attenuation of canonical NF- $\mathrm{BB}$ signaling.

Other NF-kB-target genes encode tumor-promoting, pro-inflammatory cytokines such as TNF, IL-1 and IL-6 (Interleukin 6); growth-stimulating cytokines and factors such as IL-2, GM-CSF (granulocyte-macrophage colony-stimulating factor), M-CSF and CD40L; cell-adhesion molecules such as ICAM-1 (intercellular adhesion molecule-1) and stress response mediators such as iNOS 
(inducible nitric oxide synthase). In addition, NF- $\mathrm{kB}$ factors also modulate cell-cycle progression by mediating the expression of cell-cycle regulators, such as cyclin D1. Notably, NF-KB proteins promote cell survival by triggering the expression of genes encoding anti-apoptotic proteins, such as cFLIP (cellular FLICE (FADD-like IL-1 $\beta$-converting enzyme)-inhibitory protein), Bcl-2, Bcl-xL, XIAP, cIAPs (cellular inhibitors of apoptosis) and survivin. Indeed, RelA was shown to play a critical role in protecting cells from apoptotic death [39]. The canonical NF- $\mathrm{kB}$ signaling has been implicated in both innate and adaptive immune responses to a variety of microbial substances. In particular, B cell maturation antigen (BCMA), which activates the canonical NF- $\mathrm{KB}$ pathway, was shown to be required for the maintenance of long-lived plasma cells [42,43]. Previous studies, in fact, identified NF- $\mathrm{kB}$ transcriptional signatures in plasma cells isolated from the bone marrow of healthy individuals [34]. Moreover, canonical signaling supported the survival of plasma cells in vitro [44]. These observations indicated possible engagement of the canonical pathway in normal bone-resident plasma cells in physiological settings.

\section{The Non-Canonical NF- $\kappa$ B Activation Pathway}

Activation of non-canonical NF- $\mathrm{BB}$ signaling: the non-canonical NF- $\mathrm{B}$ pathway is activated by cell-differentiating and organogenic cues, that engage B-cell maturating BAFFR (B cell activating factor receptor), CD40 (cluster of differentiation 40), osteoclast differentiating RANK (receptor activator of NF- $\mathrm{kB}$ ) or lymph node-inducing lymphotoxin- $\beta$ receptor (LT $\beta R$ ) [45]. The $N f k b 2$-encoded NF- $\mathrm{B}$ molecule p100 regulates nuclear activation of RelB NF- $\mathrm{kB}$ dimers in the non-canonical pathway (Figure 2B). As a constituent of the multimeric IкBsome complex, p100 utilizes its C-terminal ankyrin repeat domain for sequestering primarily the RelB NF- $\mathrm{kB}$ factors in the cytoplasm of unstimulated cells $[46,47]$. Non-canonical signaling requires phosphorylation and activation of IKK1 by NF-KB inducing kinase (NIK) and does not involve IKK2 or NEMO [48]. NIK, in association with activated IKK1, phosphorylates p100 [48-50]. Subsequent K48-linked polyubiquitination and proteasomal action removes the C-terminal inhibitory domain of p100 that not only generates the mature p52 NF- $\mathrm{kB}$ subunit but also liberates the RelB:p52 and the RelB:p50 NF- $\mathrm{kB}$ heterodimers from the IкBsome into the nucleus [51]. Unlike canonical signaling, which triggers a strong yet transient RelA or c-Rel containing NF- $\mathrm{BB}$ response, non-canonical signaling elicits a sustained RelB NF- $\mathrm{KB}$ activity. In physiological settings, RelB activated by non-canonical signaling isthought to play a rather limited role in immune cell maturation and immune organogenesis, including B-cell maturation, dendritic cell activation, bone homeostasis and lymphoid organogenesis. Importantly, IKK1 and RelB as well as p100 have been implicated in the survival of post-germinal center plasma cells [52,53]. If the non-canonical NF- $\mathrm{kB}$ pathway modulates the survival of long-lived bone marrow plasma cells, the healthy counterpart of myeloma cells, remains unclear.

Interestingly, NIK is regulated at the level of protein stability. A complex composed of TRAF3, TRAF2 and cIAP1/2 targets NIK for K48-linked polyubiquitination that causes proteasomal degradation of NIK in resting cells. Non-canonical stimuli degrade TRAF3 and TRAF2 and rescue NIK from the constitutive destruction; NIK then marks p100 for proteasome processing [54,55]. In addition, it was proposed that IKK1-mediated phosphorylation triggers proteasomal degradation of NIK and consequent termination of non-canonical signaling [56].

Target genes of RelB NF-KB: while immune-activating substances trigger canonical signaling, immune-differentiating cues signal through the non-canonical pathway. RelA or c-creRel dimers activated by canonical signaling induce the expression of a wide spectrum of immune and stress response genes as well as pro-survival factors. It was originally suggested that RelB NF- $\mathrm{kB}$ dimers activated by the non-canonical pathway induce preferentially the expression of genes encoding organogenic chemokines and immune differentiating factors [45]. Indeed, the RelB:p52 dimer was shown to bind to the variant kappaB site present in the promoters of homeostatic chemokine genes, including stromal cell-derived factor $1 \alpha(\mathrm{SDF} 1 \alpha)$, and selectively activate their expressions [57-59]. Accordingly, it was postulated that stimulus-selective gene-expressions are achieved through the 
engagement of distinct NF- $\mathrm{kB}$ dimers, which possess non-redundant DNA binding specificity [38]. However, this notion has been contested by several other studies. In fact, protein-binding microarrays (PBMs) and surface plasmon resonance (SPR) analyses indicated that RelA:p50, c-Rel:p50 and RelB:p52 heterodimers not only bind to identical $\mathrm{KB}$ sites, but they also show similar affinities towards DNA [60]. Moreover, ChIP-seq analyses demonstrated that various NF- $\kappa B$ subunits occupy equivalent chromatin sites in vivo [61,62]. Finally, RelB was shown to activate the expression of at least a subset of RelA-target genes, including those encoding pro-inflammatory cytokines and pro-survival factors, in mouse-derived knockout cells, specialized immune cells, and cancerous cells [63-65]. Therefore, regulatory mechanisms separate from DNA binding appear to dictate stimulus-specific expressions of NF-kB-dependent genes [66]. It is likely that dynamical control of the activated NF- $\mathrm{kB}$ dimers, signal-induced chromatin modifying events, other co-regulated transcription factors and their potentially different interaction with NF- $\mathrm{kB}$ proteins impact stimulus specific gene-expressions. Clearly, additional studies are warranted for unraveling how these individual NF- $\mathrm{kB}$-activating pathways direct specific gene-expression programs in physiological settings. For further reading on non-canonical NF-KB signaling, please see other review articles including that of Shao-Cong Sun [45].

\section{NF- $\kappa$ B Deregulating Mutations in Multiple Myeloma}

As early as in 2007, two research groups independently reported the presence of NF- $\mathrm{kB}$-activating mutations in MM [33,34]. Annunziata et al. observed NF-KB-related genetic anomalies in $28 \%$ of the MM cell lines (MMCL) and 9\% of the primary MM tumors [33]. Keats et al. examined $155 \mathrm{MM}$ samples using high-resolution array-based comparative genomic hybridization $(\mathrm{aCGH})$ and gene expression profiling (GEP) [34]. Their study mapped close to $20 \%$ of the mutational events onto the genes encoding the mediators and effectors of NF- $\mathrm{kB}$ signaling. These pioneering studies identified $\mathrm{MM}$-associated mutations in both canonical and non-canonical arms of the NF- $\mathrm{kB}$ system (Table 1). The most common genetic abnormalities affecting the canonical pathway were: gain-of-function mutations in the gene encoding the TACI receptor (transmembrane activator and CAML interactor) that mediates canonical signaling; homozygous deletions of CYLD; and amplifications of NFKB1, which produces p50. Frequently occurring genetic aberrations pertinent to the non-canonical pathway included gain-of-function mutations and amplifications of genes encoding LT $\beta$ R, CD40 and NIK; frameshift mutations and deletions associated with NFKB2 that resulted in the production of a truncated p100 devoid of the C-terminal inhibitory domain; and mutational inactivation or deletion of genes encoding negative regulators, such as TRAF2, TRAF3, cIAP1 and cIAP2.

Subsequent studies substantiated the prevalence of NF- $\mathrm{kB}$-activating mutations in MM. Parallel sequencing of 38 tumor genomes catalogued 10 point-mutations and four structural rearrangements associated with 11 distinct genes, which directly or indirectly control NF-KB functions [67]. The deregulated genes linked to canonical signaling included TLR4; TNFRSF1A, which encodes TNFR1, IKBKB, which expresses IKK2; IKBIP, which encodes an IKK2-interacting protein; CARD11, MAP3K1 and RIPK4 that code for various IKK2-activating proteins; $C Y L D ; B T R C$, which encodes a ubiquitin ligase involved in signal-induced degradation of $\mathrm{I} \kappa \mathrm{B} \alpha$. The mutated genes encoding non-canonical signal transducers included MAP3K14, which produces NIK, and TRAF3. In a separate study, samples derived from 177 and 26 myeloma patients were subjected to whole-exome and whole-genome sequencing, respectively [25]. This high-throughput analysis identified homozygous deletions in 32 genes, including CYLD and TRAF3. Similarly, 17\% of the 463 patients enrolled in the National Cancer Research Institute (UK) Myeloma XI trial possessed NF- $\mathrm{KB}$-activating mutations, which affected most frequently CYLD and TRAF3 [68]. Finally, a recent study identified recurrent loss-of-function mutations in the gene encoding the negative regulator of IKK2, A20 [35].

These mutations are associated with a diverse set of genes, but result invariably in the pathological activation of a handful of key signaling pathways, particularly the NF- $\kappa B$-activating pathways. Therefore, it is tempting to speculate that an "NF-kB-high phenotype," and not any particular 
genetic lesion, is enriched in $\mathrm{MM}$ and exacerbates the disease pathogenesis. MM-associated mutations potentially promote the nuclear activity of RelA and RelB heterodimers and trigger NF- $\mathrm{KB}$-driven gene expressions. As such, heightened NF- $\mathrm{kB}$ activity has been implicated in the growth of myeloma cells, and in their resilience against apoptotic insults. Indeed, gene expression profiling of hyperdiploid multiple myeloma revealed a distinct patient cluster characterized by the overexpression of NF- $\mathrm{kB}$-target genes, including anti-apoptotic genes [69]. Curiously, patients belonging to this NF-kB-signature cluster responded substantially better to bortezomib, a proteasome inhibitor that blocks degradation of IKBs, as compared to other patient groups (70\% versus $29 \%$; $p=0.02)$. This study underscored the importance of mutational activation of NF- $\mathrm{KB}$ signaling in the pathogenesis of MM.

\section{NF-KB-Related Microenvironmental Cues in Multiple Myeloma}

Unlike most other hematological malignancies, development of symptomatic myeloma obligatorily involves a tumor-promoting microenvironment that is provided by the bone marrow niche [70,71]. Within the bone marrow microenvironment, myeloma cells interact with accessory cells, including bone marrow stromal cells (BMSCs), osteoclasts, osteoblasts and endothelial cells. These physical contacts provoke tumor-associated non-cancerous cells to produce various soluble factors, including cytokines and chemokines. Cell-cell communications involving physical interactions as well as soluble mediators, which engage autocrine and paracrine loops, activate NF- $\mathrm{KB}$ and other key signaling pathways in both non-malignant and malignant cells. Heightened NF- $\mathrm{kB}$ signaling leads to further accumulation of tumor-promoting cytokines and growth factors, which support growth, survival and drug-resistance of myeloma cells [70].

For example, IL-6 acts as an important growth and survival factor in MM. Upon adhering to myeloma cells, BMSCs activate the canonical NF- $\mathrm{kB}$ pathway, which induces the expression of IL-6 [72]. Additionally, myeloma cell-derived IL-1 $\beta$, also encoded by an NF-kB-target gene, promotes IL-6 production by inducing canonical NF-kB signaling in BMSCs [73]. In turn, IL-6 binds to the cognate receptor and induces pro-proliferative and pro-survival gene-expressions in myeloma cells. Furthermore, IL-6 induces the production of vascular endothelial growth factor (VEGF), which promotes angiogenesis and neovascularization in the tumor microenvironment [74]. Importantly, some of the VEGF isoforms are encoded by NF- $\mathrm{kB}$-target genes [75]. Bone marrow stromal cells also secrete insulin-like growth factor 1 (IGF1), which in myeloma cells induces NF- $\kappa B$-dependent expression of anti-apoptotic genes [76,77]. Pro-inflammatory cytokine TNF activates canonical NF- $\mathrm{kB}$ signaling in both BMSCs as well as myeloma cells, and is also produced by the canonical pathway. TNF not only supports the pro-inflammatory tumor microenvironment but also induces the expression of important NF- $\mathrm{KB}$-target pro-survival factors in myeloma cells [78]. Indeed, disruption of the TNF autocrine loop was shown to sensitize myeloma cells to apoptosis-inducing anticancer drugs ex vivo [79]. More so, it has been suggested that therapeutic efficacy of thalidomide and lenalidomide in MM in part relies on their ability to inhibit pro-inflammatory cytokines such as TNF- $\alpha$, IL-1 $\beta$, and IL-6 $[80,81]$.

MM is also associated with an increased abundance of B-cell activating factor (BAFF), which activates non-canonical NF- $\mathrm{KB}$ signaling via BAFFR in addition to TACI-mediated induction of the canonical pathway [82]. As such, BAFF is thought to support growth and survival of myeloma cells and contribute to poor disease prognosis [83]. Importantly, a proliferation-inducing ligand (APRIL) also signals through TACI as well as BCMA, and constitutes an important bone-marrow microenvironmental factor in MM [70]. Of note, targeting of BCMA in chimeric antigen receptor $\mathrm{T}$ cell (CAR-T cell) based therapy of MM produced promising results in initial clinical trials [84]. Moreover, myeloma cells produce RANKL, which promotes MM-associated bone loss by inducing osteoclast differentiation through the non-canonical NF- $\mathrm{kB}$ pathway [85]. It was shown that physical interaction of myeloma cells with the extracellular matrix (ECM) component fibronectin per se induces a RelB-dependent, pro-survival NF-kB signaling in cancerous cells [86]. Finally, non-canonical signaling in BMSCs produce the RelB-target homeostatic chemokine SDF1 $\alpha$, which directs homing of myeloma 
cells to the bone marrow niche [87]. In sum, autocrinal as well as paracrinal cytokine signals, cell-cell and cell-ECM adhesion mechanisms seem to activate both canonical and non-canonical NF- $\kappa$ B signaling in myeloma cells as well as in tumor-associated non-malignant cells.

\section{Interactions between NF-кB Signaling Pathways and Multiple Myeloma}

Concomitant activation of canonical and non-canonical NF- $\kappa$ B signaling in MM: a heightened activity of the canonical NF- $\kappa B$ pathway has been reported in several human malignancies. In MM, both genetic mutations and microenvironmental cues trigger this pathway. Canonical signaling induces the RelA NF- $\mathrm{kB}$ activity, which stimulates the transcription of genes encoding pro-inflammatory cytokines and pro-survival factors. However, canonical signaling generally induces a rather transient RelA activity ex vivo owing to negative feedback regulations. Genetic lesions and to some extent, tumor microenvironmental cues additionally activate the non-canonical NF- $\kappa$ B pathway in myeloma cells. In fact, frequent engagement of non-canonical signaling constitutes a prominent feature of MM [65]. However, the non-canonical pathway induces a sustained RelB NF- $\kappa$ B activity, which mediates the expression of mostly immune differentiating and immune organogenic factors in physiological settings. Considering relatively limited physiological functions of RelB in immune maturation, a preponderance of mutations in the non-canonical pathway in MM appears somewhat puzzling. Nevertheless, mutational activations of non-canonical signaling have been described in other hematological malignancies, including chronic lymphocytic leukemia (CLL), T-cell lymphoma and cutaneous Band T-cell lymphomas [88]. Mechanistic analyses by several groups elucidated that the canonical and the non-canonical pathways are interdependently regulated [89]. As elaborated below (Figure 3), we propose that dysfunctions of an integrated NF-kB system, and not that of the individual canonical and non-canonical pathways, cause pathological NF- $\mathrm{B}$ activity in MM. In other words, an integrated NF- $\kappa B$ system multiplies the effect of cancer-associated non-canonical signaling and causes deregulation of several NF- $\mathrm{kB}$ factors.

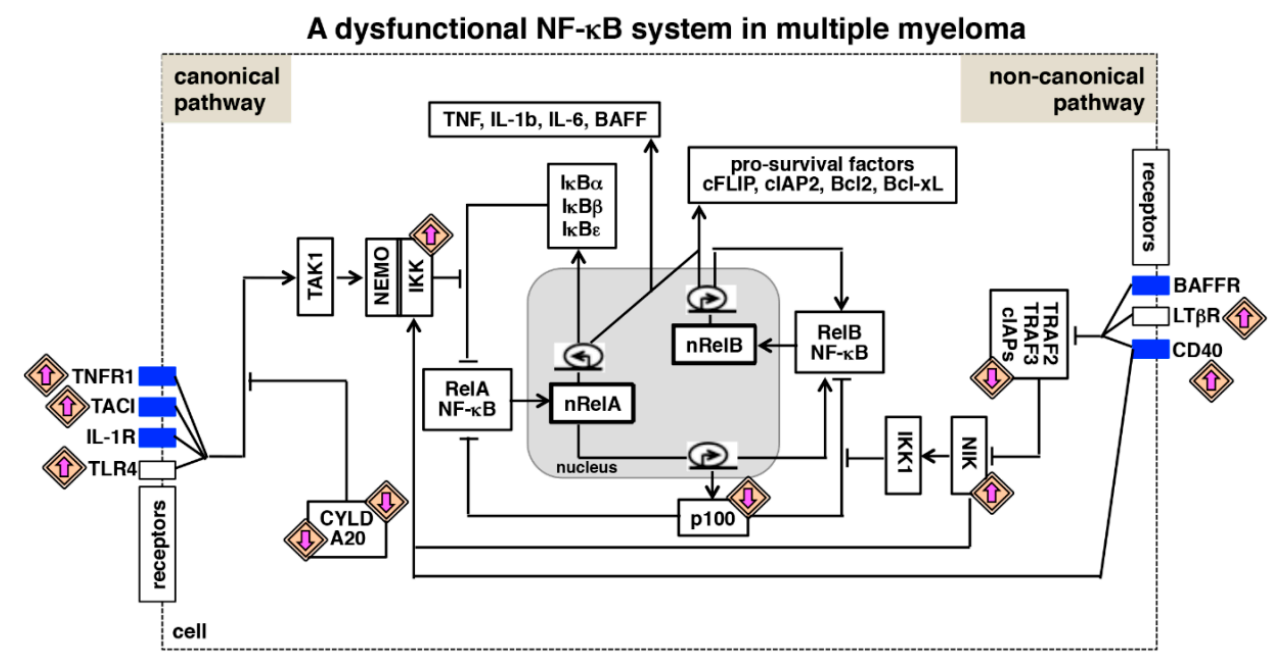

Figure 3. A dysfunctional NF- $\mathrm{B}$ system in multiple myeloma. Various biochemical mechanisms interlink NF- $k B$-activating canonical and non-canonical pathways within an integrated NF- $\mathrm{kB}$ system. Also in myeloma cells, RelA and RelB containing dimers mediate expressions of overlapping set of anti-apoptotic genes. Multiple myeloma is associated with the gain-of-function mutation (upward directed purple arrow) of genes encoding NF- $\mathrm{kB}$ activators and the loss-of-function mutation (downward directed purple arrow) of genes encoding inhibitors of the NF- $\mathrm{kB}$ system. In addition, tumor microenvironment-derived factors trigger aberrant activation of cytokine receptor signaling (blue rectangle) in myeloma cells. As such, genetic and microenvironmental factors activate both the NF- $\kappa B$ activating pathways, and interdependent regulation of these pathways promotes pathological NF- $\kappa B$ activity and reinforces NF- $\mathrm{BB}$-driven expressions of pro-survival genes in myeloma cells. 
RelA NF-кB activation by non-canonical signals: Mechanistic studies involving mouse embryonic fibroblasts (MEFs) and B cells revealed that p100 retained not only RelB but also a sub-population of RelA and c-Rel subunits within the IkBsome complex [46,90-92]. Consistently, disruption of the IKBsome by LT $\beta R$-induced non-canonical signaling led to concomitant nuclear activation of both RelA and RelB NF-kB dimers [90]. Furthermore, NIK was shown to modulate directly the activity of the NEMO-IKK complex, which controls the canonical RelA NF- $\mathrm{kB}$ response [93]. Mutational activation of NIK indeed induced both canonical and non-canonical NF- $\kappa$ B signaling in MMCLs [94]. In comparison to targeting one or the other pathway, dual inhibition of mediators of both the pathways achieved significantly more anti-tumor activities in preclinical studies, which involved MMCLs, primary patient-derived cells, and xenograft murine models $[95,96]$. Therefore, it appears that NF- $\kappa B$ activating pathways are interlinked in MM and cooperate for promoting growth and survival of myeloma cells.

RelB:p50 NF-кB activation by canonical signals: interestingly, canonical TNF signaling induced an additional, long-lasting RelB:p50 activity in $N f k b 2^{-/-} \mathrm{MEFs,} \mathrm{which} \mathrm{lacked} \mathrm{the} \mathrm{expression} \mathrm{of}$ the non-canonical signal transducer p100 [63,97]. RelB is encoded by a NF-kB target gene [98]. Mechanistic studies clarified that RelA-dependent as well as autoregulatory mechanisms strengthened TNF-induced synthesis of RelB, which accumulated in the nucleus as an enduring NF- $\kappa \mathrm{B}$ activity in the absence of the inhibitory p100 [63]. Curiously, it was demonstrated that Fbxw7 (F-box/WD40 repeat-containing protein 7), which supports the degradative K48-linked polyubiquitination of proteins, marked p100 for complete degradation in myeloma cells [99]. Likewise, mutational activation of the non-canonical pathway was associated with complete degradation of p100 in MMCLs [63]. Remarkably, NF-кB dependent RelB synthesis perpetuated a sustained RelB:p50 activity upon TNF stimulation of these myeloma cells. This TNF-induced RelB activity was implicated in the resistance of MMCLs harboring non-canonical pathway mutations to TRAIL-mediated apoptosis. Furthermore, RELB mRNA levels inversely correlated with the response of MM patients to therapeutic interventions [63]. In sum, genetic aberrations chronically activated the non-canonical pathway in myeloma cells that led to complete degradation of p100, instead of its partial processing into p52. p100-depleted malignant cells utilized the canonical TNF signal for eliciting a sustained, pro-survival NF- $\kappa$ B activity, which was composed of the RelB:p50 dimer and dependent on the NF- $\mathrm{B}-$ driven RelB synthesis. Notably, RelA-dependent RelB synthesis was implicated in the activation of the RelB:p50 dimer in transformed B-cells [100] and invasive breast cancer cells [101]. Finally, MM-associated mutations in the non-canonical pathway seem to exacerbate the drug-resistance of malignant cells by altering the composition, and the dynamical control of the canonical NF- $\mathrm{KB}$ activity induced by microenvironmental cues, such as TNF.

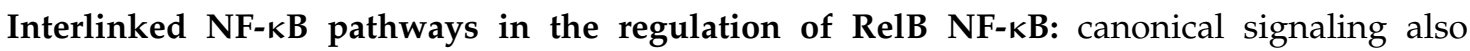
modulates the RelB:p52 activity induced by non-canonical inducers. RelA upregulates the transcription of $N f k b 2$, which encodes p100 [102]. It was demonstrated that BCR-induced canonical signaling abundantly produced p100 in mature B cells, and that apt conversion of this p100 into p52 by the BAFF-stimulated non-canonical pathway generated a robust RelB:p52 response [103]. On the other hand, an absence of RelA abrogated RelB synthesis and LT $\beta R$-induced RelB activity [97]. It was also proposed that p50 and p52 were generated in mouse-derived cells through an interdependent proteasomal processing mechanism involving the respective precursor proteins p105 and p100 [97,104]. Interestingly, CD40 simultaneously activates both the NF- $\mathrm{B}$ pathways and is widely expressed on myeloma cells $[105,106]$. Engagement of CD40 enhances adhesion of myeloma cells to extracellular matrix proteins and BMSCs, and induces the production of IL-6 and VEGF by malignant cells. In fact, anti-CD40 monoclonal antibodies have been evaluated in clinical trials involving MM patients [107]. Despite the role of CD40 in the pathogenesis of the disease, CD40-mediated regulation of the RelB NF- $\kappa B$ activity has not been investigated in the context of multiple myeloma. It remains unclear if CD40-activated non-canonical signaling degrades p100 completely to promote canonical RelB:p50 activation, or crosstalk between CD40-induced NF-кB pathways contributes to aberrant RelB:p52 
activation myeloma cells. It is likely that other microenvironmental and genetic factors, either alone or in combination, concurrently activate both the pathways in multiple myeloma. In this context, it will be important to investigate further if ongoing canonical signaling reinforces the RelB NF- $\mathrm{KB}$ activity induced by the non-canonical pathway in cancerous cells. Considering that dysfunctions associated with an integrated NF- $\mathrm{KB}$ system appears to cause myeloma-associated inappropriate NF- $\mathrm{KB}$ activation, further studies ought to delineate the molecular connectivity between NF- $\mathrm{BB}$ pathways in diseased cells.

\section{NF- $\kappa$ B Driven Gene Expressions in Myeloma Cells}

Aberrant activation of the NF- $\mathrm{kB}$ family of transcription factors in myeloma cells causes heightened expressions of a variety of tumor-promoting cytokines, which further act in an autocrine loop on malignant cells. Clinical studies involving serum and bone marrow samples derived from MM patients revealed a substantially augmented level of TNF, IL-1, IL-6 and BAFF [108-111]. Analysis of MMCLs confirmed that myeloma cells were indeed capable of inducing the expression of genes encoding tumor-promoting cytokines. In addition, enduring NF- $\mathrm{kB}$ signaling stimulated cancer cell-intrinsic expressions of pro-survival factors, including cFLIP, cIAP2, Bcl-xL, Bcl2 and Gadd $45 \beta[63,65,112]$. These pro-survival factors promoted myeloma growth and imparted resilience in cancerous cells from apoptosis-inducing chemotherapeutic agents. In addition, NF- $\mathrm{kB}$ signaling has been also implicated in the elevated expression of proto-oncogenes encoding c-Myc as well as c-Myb [113,114]. Finally, cell adhesion molecules, such as ICAM1, were produced by tumor cells in a NF-kB-dependent manner.

It is generally thought that primarily RelA-containing heterodimers mediate the transcription of NF- $\kappa B$ target genes from the $\kappa \mathrm{B}$-driven promoters, while RelB heterodimers stimulate selectively the expression of immune differentiating factors. However, biophysical and biochemical analyses pointed out that RelA and RelB dimers possessed rather overlapping $\mathrm{kB}$ DNA binding specificities [60-62]. Furthermore, it was shown that a reduced p100 level in dendritic cells enabled RelB:p50 activation by canonical signaling and that the RelB:p50 heterodimer induced by the canonical pathway mediated the expression of certain RelA-target genes [64]. Subsequently, Roy et al. (2017) utilized a panel of mouse-derived knockout cells devoid of one or more NF- $\mathrm{kB}$ subunits to examine the gene-expression specificity of NF-kB heterodimers [63]. Their global-scale mRNA analyses established that RelB:p50 could largely substitute the RelA:p50 heterodimer for mediating TNF-induced expressions of NF- $\mathrm{KB}$ target genes, including those encoding pro-survival factors. Interestingly, over-expression of IKK, which selectively activates canonical signaling, or the non-canonical signal transducer NIK led to inductions of nearly overlapping set of genes in MMCLs [94]. These studies indicated that RelA and RelB heterodimers might coordinately control NF- $\mathrm{kB}$ driven gene-expressions in MM.

In contrast to its rather limited physiological functions, RelB was reported to play a critical role in promoting survival and drug resistance of myeloma cells. This pro-survival RelB function was attributed to RelB-dependent expressions of anti-apoptotic genes [63,65,86]. Cormier et al. (2013) demonstrated that $\sim 40 \%$ of newly diagnosed MM patients possessed tumor cells with heightened nuclear RelB:p50 DNA binding activity. Their analysis further disclosed that RelB directly bound to the promoter of several NF- $\mathrm{kB}$ target pro-survival genes and activated their expressions in MMCLs [65]. In MMCLs harboring gain-of-function mutations in the non-canonical NF- $\mathrm{KB}$ module, TNF activated the RelB:p50 heterodimer, which similarly sustained the transcription of pro-survival genes, including cFLIP and Bcl2 [63]. These studies identified RelB as a potent activator of pro-survival genes in myeloma cells. However, a recent study revealed that a HDAC4-RelB complex inhibited the transcription of pro-apoptotic gene Bim in MMCLs [54]. Further mechanistic investigations are warranted to unravel if RelB indeed functions as an activator and a repressor in different subsets of myeloma cells. Nevertheless, not only mutations onto the non-canonical NF- $\mathrm{kB}$ module are prevalent in $\mathrm{MM}$, but RelB NF-KB dimers also appear to supplement pathological RelA functions in myeloma cells. 
Taken together, intimately interlinked NF-KB pathways and a set of NF- $\mathrm{kB}$ transcription factors with overlapping gene-expression specificities perpetuate pro-survival signaling in myeloma cells.

\section{Conclusions}

Signals derived from diverse genetic and microenvironmental factors converge predominantly onto the NF- $\mathrm{KB}$ system in myeloma cells, highlighting the seminal role of NF- $\mathrm{BB}$ in the pathogenesis of $\mathrm{MM}$. In myeloma cells, cell-intrinsic mutations activate mostly the non-canonical NF- $\mathrm{kB}$ pathway, whereas tumor microenvironment-derived cytokines trigger largely canonical signaling. Emerging evidence suggests that crosstalk between the NF- $\mathrm{kB}$-activating pathways integrates mutational and microenvironmental signals to provoke anomalous NF- $\mathrm{KB}$ activation in MM. In particular, NIK-dependent non-canonical signaling amplifies RelA NF- $\mathrm{kB}$ responses and canonical signaling reinforces RelB NF- $\mathrm{kB}$ activity in myeloma cells. Importantly, RelB-containing heterodimers play a broader role in MM. They mediate the expression of pro-survival genes, which are traditionally thought to be RelA targets, and supplement the anti-apoptotic RelA function by protecting myeloma cells from apoptotic, chemotherapeutic drugs. We hypothesize that an integrated NF- $\mathrm{kB}$ system should be considered in sum, for understanding further NF- $\mathrm{kB}$ deregulations in MM.

The constituents of the non-canonical pathway contribute to the pro-survival and pro-proliferative program of myeloma cells via the integrated NF- $\kappa B$ system. In fact, an overarching role of non-canonical signaling in MM led to active consideration of NIK as a promising drug target [115]. Future studies should further characterize interdependent regulations of NF- $\mathrm{kB}$ pathways in MM, as these crosstalk connectivities may guide disease state-specific therapeutic interventions involving dual inhibition of both the NF-kB-activating pathways. Moreover, it remains unclear if the myeloma-associated RelB only activates the expression of RelA-target pro-survival genes or also mediates the expression of genes that are normally not induced by RelA. Global transcriptomic and chromatin-binding analyses involving mouse-derived knockout cells may offer valuable insights on the identity of RelA-target, RelB-target and generic NF- $\mathrm{kB}$-dependent genes. These NF- $\mathrm{kB}$ gene signatures can be exploited for interrogating genome-scale data obtained from MM patients for assessing possible involvement of NF- $\mathrm{kB}$ pathways in the disease pathogenesis. Based on the outcome of such studies involving longitudinal cohorts, the NF- $\mathrm{KB}$ gene signatures can be further utilized as prognostic tools for predicting disease outcome, response to therapy, and the survival parameters of newly diagnosed MM patients. Furthermore, such analyses can potentially inform personalized treatment regimes for achieving efficacious and specific therapeutic interventions involving the NF- $\mathrm{kB}$ system. Finally, it is known that only a subset of MGUS progresses into MM. Recent high-throughput genome sequencing studies indicated that NF-kB-activating mutations are rather rare in the MGUS stage as compared to MM $[116,117]$. In this context, global transcriptomic analyses ought to address whether bone marrow-derived cues trigger uncontrolled NF- $\mathrm{kB}$ activation in MGUS and if such NF- $\mathrm{kB}$ deregulations precede the transition of MGUS into MM. An understanding of the mechanism that drives benign MGUS into malignant MM may enable the development of preventive measures. In conclusion, a multi-disciplinary approach, which involves mechanistic and clinical studies, will be indispensable for improving further therapeutic modalities in multiple myeloma.

Author Contributions: P.R. and U.A.S. carried out the literature survey under the supervision of S.B., S.B. wrote the review article with P.R.

Funding: Multiple Myeloma research and NF- $\mathrm{kB}$ signaling studies in the Systems Immunology Laboratory were funded by SERB, Department of Science and Technology, Govt. of India (EMR/2015/000658), the Wellcome Trust DBT India Alliance (500094/Z/09/Z) and NII-core.

Acknowledgments: We gratefully acknowledge critical comments and helpful suggestions received from the members of the Systems Immunology Laboratory on the manuscript.

Conflicts of Interest: The authors declare no conflict of interest. 


\section{References}

1. Ferlay, J.; Shin, H.R.; Bray, F.; Forman, D.; Mathers, C.; Parkin, D.M. Estimates of worldwide burden of cancer in 2008: Globocan 2008. Int. J. Cancer 2010, 127, 2893-2917. [CrossRef] [PubMed]

2. Jemal, A.; Siegel, R.; Ward, E.; Hao, Y.; Xu, J.; Thun, M.J. Cancer statistics, 2009. CA Cancer J. Clin. 2009, 59, 225-249. [CrossRef] [PubMed]

3. Kazandjian, D. Multiple myeloma epidemiology and survival: A unique malignancy. Semin. Oncol. 2016, 43, 676-681. [CrossRef] [PubMed]

4. Palumbo, A.; Anderson, K. Multiple myeloma. N. Engl. J. Med. 2011, 364, 1046-1060. [CrossRef] [PubMed]

5. Flores-Montero, J.; de Tute, R.; Paiva, B.; Perez, J.J.; Bottcher, S.; Wind, H.; Sanoja, L.; Puig, N.; Lecrevisse, Q.; Vidriales, M.B.; et al. Immunophenotype of normal vs. Myeloma plasma cells: Toward antibody panel specifications for mrd detection in multiple myeloma. Cytom. B Clin. Cytom. 2016, 90, 61-72. [CrossRef] [PubMed]

6. Gonzalez, D.; van der Burg, M.; Garcia-Sanz, R.; Fenton, J.A.; Langerak, A.W.; Gonzalez, M.; van Dongen, J.J.; San Miguel, J.F.; Morgan, G.J. Immunoglobulin gene rearrangements and the pathogenesis of multiple myeloma. Blood 2007, 110, 3112-3121. [CrossRef] [PubMed]

7. Mahindra, A.; Hideshima, T.; Anderson, K.C. Multiple myeloma: Biology of the disease. Blood Rev. 2010, 24 (Suppl. 1), S5-S11. [CrossRef]

8. Kyle, R.A.; Rajkumar, S.V. Multiple myeloma. N. Engl. J. Med. 2004, 351, 1860-1873. [CrossRef] [PubMed]

9. Chim, C.S.; Kumar, S.K.; Orlowski, R.Z.; Cook, G.; Richardson, P.G.; Gertz, M.A.; Giralt, S.; Mateos, M.V.; Leleu, X.; Anderson, K.C. Management of relapsed and refractory multiple myeloma: Novel agents, antibodies, immunotherapies and beyond. Leukemia 2018, 32, 252-262. [CrossRef] [PubMed]

10. Fonseca, R.; Bergsagel, P.L.; Drach, J.; Shaughnessy, J.; Gutierrez, N.; Stewart, A.K.; Morgan, G.; Van Ness, B.; Chesi, M.; Minvielle, S.; et al. International myeloma working group molecular classification of multiple myeloma: Spotlight review. Leukemia 2009, 23, 2210-2221. [CrossRef] [PubMed]

11. Avet-Loiseau, H.; Attal, M.; Moreau, P.; Charbonnel, C.; Garban, F.; Hulin, C.; Leyvraz, S.; Michallet, M.; Yakoub-Agha, I.; Garderet, L.; et al. Genetic abnormalities and survival in multiple myeloma: The experience of the intergroupe francophone du myelome. Blood 2007, 109, 3489-3495. [CrossRef] [PubMed]

12. Corre, J.; Munshi, N.; Avet-Loiseau, H. Genetics of multiple myeloma: Another heterogeneity level? Blood 2015, 125, 1870-1876. [CrossRef] [PubMed]

13. Robiou du Pont, S.; Cleynen, A.; Fontan, C.; Attal, M.; Munshi, N.; Corre, J.; Avet-Loiseau, H. Genomics of multiple myeloma. J. Clin. Oncol. 2017, 35, 963-967. [CrossRef] [PubMed]

14. Sawyer, J.R.; Waldron, J.A.; Jagannath, S.; Barlogie, B. Cytogenetic findings in 200 patients with multiple myeloma. Cancer Genet. Cytogenet. 1995, 82, 41-49. [CrossRef]

15. Chesi, M.; Bergsagel, P.L.; Brents, L.A.; Smith, C.M.; Gerhard, D.S.; Kuehl, W.M. Dysregulation of cyclin $\mathrm{D} 1$ by translocation into an IgH gamma switch region in two multiple myeloma cell lines. Blood 1996, 88, 674-681. [PubMed]

16. Chesi, M.; Nardini, E.; Brents, L.A.; Schrock, E.; Ried, T.; Kuehl, W.M.; Bergsagel, P.L. Frequent translocation $\mathrm{t}(4 ; 14)(\mathrm{p} 16.3 ; \mathrm{q} 32.3)$ in multiple myeloma is associated with increased expression and activating mutations of fibroblast growth factor receptor 3. Nat. Genet. 1997, 16, 260-264. [CrossRef] [PubMed]

17. Chesi, M.; Nardini, E.; Lim, R.S.; Smith, K.D.; Kuehl, W.M.; Bergsagel, P.L. The t(4;14) translocation in myeloma dysregulates both FGFR3 and a novel gene, MMSET, resulting in igH/MMSET hybrid transcripts. Blood 1998, 92, 3025-3034. [PubMed]

18. Hurt, E.M.; Wiestner, A.; Rosenwald, A.; Shaffer, A.L.; Campo, E.; Grogan, T.; Bergsagel, P.L.; Kuehl, W.M.; Staudt, L.M. Overexpression of c-maf is a frequent oncogenic event in multiple myeloma that promotes proliferation and pathological interactions with bone marrow stroma. Cancer Cell 2004, 5, 191-199. [CrossRef]

19. Hanamura, I.; Iida, S.; Akano, Y.; Hayami, Y.; Kato, M.; Miura, K.; Harada, S.; Banno, S.; Wakita, A.; Kiyoi, H.; et al. Ectopic expression of MAFB gene in human myeloma cells carrying (14;20)(q32;q11) chromosomal translocations. Jpn. J. Cancer Res. 2001, 92, 638-644. [CrossRef] [PubMed]

20. Bergsagel, P.L.; Kuehl, W.M.; Zhan, F.; Sawyer, J.; Barlogie, B.; Shaughnessy, J., Jr. Cyclin d dysregulation: An early and unifying pathogenic event in multiple myeloma. Blood 2005, 106, 296-303. [CrossRef] [PubMed] 
21. Avet-Loiseau, H.; Li, C.; Magrangeas, F.; Gouraud, W.; Charbonnel, C.; Harousseau, J.L.; Attal, M.; Marit, G.; Mathiot, C.; Facon, T.; et al. Prognostic significance of copy-number alterations in multiple myeloma. J. Clin. Oncol. 2009, 27, 4585-4590. [CrossRef] [PubMed]

22. Walker, B.A.; Leone, P.E.; Jenner, M.W.; Li, C.; Gonzalez, D.; Johnson, D.C.; Ross, F.M.; Davies, F.E.; Morgan, G.J. Integration of global snp-based mapping and expression arrays reveals key regions, mechanisms, and genes important in the pathogenesis of multiple myeloma. Blood 2006, 108, 1733-1743. [CrossRef] [PubMed]

23. Hanamura, I.; Stewart, J.P.; Huang, Y.; Zhan, F.; Santra, M.; Sawyer, J.R.; Hollmig, K.; Zangarri, M.; Pineda-Roman, M.; van Rhee, F.; et al. Frequent gain of chromosome band 1q21 in plasma-cell dyscrasias detected by fluorescence in situ hybridization: Incidence increases from MGUS to relapsed myeloma and is related to prognosis and disease progression following tandem stem-cell transplantation. Blood 2006, 108, 1724-1732. [CrossRef] [PubMed]

24. Chesi, M.; Bergsagel, P.L. Molecular pathogenesis of multiple myeloma: Basic and clinical updates. Int. J. Hematol. 2013, 97, 313-323. [CrossRef] [PubMed]

25. Lohr, J.G.; Stojanov, P.; Carter, S.L.; Cruz-Gordillo, P.; Lawrence, M.S.; Auclair, D.; Sougnez, C.; Knoechel, B.; Gould, J.; Saksena, G.; et al. Widespread genetic heterogeneity in multiple myeloma: Implications for targeted therapy. Cancer Cell 2014, 25, 91-101. [CrossRef] [PubMed]

26. Bolli, N.; Avet-Loiseau, H.; Wedge, D.C.; Van Loo, P.; Alexandrov, L.B.; Martincorena, I.; Dawson, K.J.; Iorio, F.; Nik-Zainal, S.; Bignell, G.R.; et al. Heterogeneity of genomic evolution and mutational profiles in multiple myeloma. Nat. Commun. 2014, 5, 2997. [CrossRef] [PubMed]

27. Neri, A.; Baldini, L.; Trecca, D.; Cro, L.; Polli, E.; Maiolo, A.T. p53 gene mutations in multiple myeloma are associated with advanced forms of malignancy. Blood 1993, 81, 128-135. [PubMed]

28. Affer, M.; Chesi, M.; Chen, W.G.; Keats, J.J.; Demchenko, Y.N.; Roschke, A.V.; Van Wier, S.; Fonseca, R.; Bergsagel, P.L.; Kuehl, W.M. Promiscuous MYC locus rearrangements hijack enhancers but mostly super-enhancers to dysregulate myc expression in multiple myeloma. Leukemia 2014, 28, 1725-1735. [CrossRef] [PubMed]

29. Lionetti, M.; Neri, A. Utilizing next-generation sequencing in the management of multiple myeloma. Expert Rev. Mol. Diagn. 2017, 17, 653-663. [CrossRef] [PubMed]

30. Bustoros, M.; Mouhieddine, T.H.; Detappe, A.; Ghobrial, I.M. Established and novel prognostic biomarkers in multiple myeloma. Am. Soc. Clin. Oncol. Educ. Book 2017, 37, 548-560. [CrossRef] [PubMed]

31. Lohr, J.G.; Kim, S.; Gould, J.; Knoechel, B.; Drier, Y.; Cotton, M.J.; Gray, D.; Birrer, N.; Wong, B.; Ha, G.; et al. Genetic interrogation of circulating multiple myeloma cells at single-cell resolution. Sci. Transl. Med. 2016, 8, 363ra147. [CrossRef] [PubMed]

32. Kumar, S.K.; Rajkumar, V.; Kyle, R.A.; van Duin, M.; Sonneveld, P.; Mateos, M.V.; Gay, F.; Anderson, K.C. Multiple myeloma. Nat. Rev. Dis. Prim. 2017, 3, 17046. [CrossRef] [PubMed]

33. Annunziata, C.M.; Davis, R.E.; Demchenko, Y.; Bellamy, W.; Gabrea, A.; Zhan, F.; Lenz, G.; Hanamura, I.; Wright, G.; Xiao, W.; et al. Frequent engagement of the classical and alternative NF-kappaB pathways by diverse genetic abnormalities in multiple myeloma. Cancer Cell 2007, 12, 115-130. [CrossRef] [PubMed]

34. Keats, J.J.; Fonseca, R.; Chesi, M.; Schop, R.; Baker, A.; Chng, W.J.; Van Wier, S.; Tiedemann, R.; Shi, C.X.; Sebag, M.; et al. Promiscuous mutations activate the noncanonical NF-kappaB pathway in multiple myeloma. Cancer Cell 2007, 12, 131-144. [CrossRef] [PubMed]

35. Troppan, K.; Hofer, S.; Wenzl, K.; Lassnig, M.; Pursche, B.; Steinbauer, E.; Wiltgen, M.; Zulus, B.; Renner, W.; Beham-Schmid, C.; et al. Frequent down regulation of the tumor suppressor gene a20 in multiple myeloma. PLoS ONE 2015, 10, e0123922. [CrossRef] [PubMed]

36. Baud, V.; Karin, M. Is NF-kappaB a good target for cancer therapy? Hopes and pitfalls. Nat. Rev. Drug Discov. 2009, 8, 33-40. [CrossRef] [PubMed]

37. DiDonato, J.A.; Mercurio, F.; Karin, M. NF-kappaB and the link between inflammation and cancer. Immunol. Rev. 2012, 246, 379-400. [CrossRef] [PubMed]

38. Hoffmann, A.; Natoli, G.; Ghosh, G. Transcriptional regulation via the NF-kappaB signaling module. Oncogene 2006, 25, 6706-6716. [CrossRef] [PubMed]

39. Oeckinghaus, A.; Ghosh, S. The NF-kappaB family of transcription factors and its regulation. Cold Spring Harb. Perspect. Biol. 2009, 1, a000034. [CrossRef] [PubMed] 
40. Chen, Z.J. Ubiquitination in signaling to and activation of ikk. Immunol. Rev. 2012, 246, 95-106. [CrossRef] [PubMed]

41. Mitchell, S.; Vargas, J.; Hoffmann, A. Signaling via the nfkappab system. Wiley Interdiscip. Rev. Syst. Biol. Med. 2016, 8, 227-241. [CrossRef][PubMed]

42. O'Connor, B.P.; Raman, V.S.; Erickson, L.D.; Cook, W.J.; Weaver, L.K.; Ahonen, C.; Lin, L.L.; Mantchev, G.T.; Bram, R.J.; Noelle, R.J. Bcma is essential for the survival of long-lived bone marrow plasma cells. J. Exp. Med. 2004, 199, 91-98. [CrossRef] [PubMed]

43. Hatzoglou, A.; Roussel, J.; Bourgeade, M.F.; Rogier, E.; Madry, C.; Inoue, J.; Devergne, O.; Tsapis, A. TNF receptor family member BCMA (B cell maturation) associates with tnf receptor-associated factor (TRAF) 1, TRAF2, and TRAF3 and activates NF-kappa B, elk-1, c-jun N-terminal kinase, and p38 mitogen-activated protein kinase. J. Immunol. 2000, 165, 1322-1330. [CrossRef] [PubMed]

44. Jourdan, M.; Cren, M.; Robert, N.; Bollore, K.; Fest, T.; Duperray, C.; Guilloton, F.; Hose, D.; Tarte, K.; Klein, B. IL-6 supports the generation of human long-lived plasma cells in combination with either april or stromal cell-soluble factors. Leukemia 2014, 28, 1647-1656. [CrossRef] [PubMed]

45. Sun, S.C. The noncanonical NF-kappaB pathway. Immunol. Rev. 2012, 246, 125-140. [CrossRef] [PubMed]

46. Savinova, O.V.; Hoffmann, A.; Ghosh, G. The NFKB1 and NFKB2 proteins p105 and p100 function as the core of high-molecular-weight heterogeneous complexes. Mol. Cell 2009, 34, 591-602. [CrossRef] [PubMed]

47. Tao, Z.; Fusco, A.; Huang, D.B.; Gupta, K.; Young Kim, D.; Ware, C.F.; Van Duyne, G.D.; Ghosh, G. p100/ikappabdelta sequesters and inhibits NF-kappaB through kappaBsome formation. Proc. Natl. Acad. Sci. USA 2014, 111, 15946-15951. [CrossRef] [PubMed]

48. Xiao, G.; Harhaj, E.W.; Sun, S.C. NF-kappaB-inducing kinase regulates the processing of NF-kappaB2 p100. Mol. Cell 2001, 7, 401-409. [CrossRef]

49. Polley, S.; Passos, D.O.; Huang, D.B.; Mulero, M.C.; Mazumder, A.; Biswas, T.; Verma, I.M.; Lyumkis, D.; Ghosh, G. Structural basis for the activation of IKK1/alpha. Cell Rep. 2016, 17, 1907-1914. [CrossRef] [PubMed]

50. Senftleben, U.; Cao, Y.; Xiao, G.; Greten, F.R.; Krahn, G.; Bonizzi, G.; Chen, Y.; Hu, Y.; Fong, A.; Sun, S.C.; et al. Activation by IKKalpha of a second, evolutionary conserved, NF-kappa B signaling pathway. Science 2001, 293, 1495-1499. [CrossRef] [PubMed]

51. Fong, A.; Sun, S.C. Genetic evidence for the essential role of beta-transducin repeat-containing protein in the inducible processing of NF-kappa B2/p100. J. Biol. Chem. 2002, 277, 22111-22114. [CrossRef] [PubMed]

52. Mills, D.M.; Bonizzi, G.; Karin, M.; Rickert, R.C. Regulation of late B cell differentiation by intrinsic IKKalpha-dependent signals. Proc. Natl. Acad. Sci. USA 2007, 104, 6359-6364. [CrossRef] [PubMed]

53. De Silva, N.S.; Anderson, M.M.; Carette, A.; Silva, K.; Heise, N.; Bhagat, G.; Klein, U. Transcription factors of the alternative NF-kappaB pathway are required for germinal center B-cell development. Proc. Natl. Acad. Sci. USA 2016, 113, 9063-9068. [CrossRef] [PubMed]

54. Vallabhapurapu, S.; Matsuzawa, A.; Zhang, W.; Tseng, P.H.; Keats, J.J.; Wang, H.; Vignali, D.A.; Bergsagel, P.L.; Karin, M. Nonredundant and complementary functions of TRAF2 and TRAF3 in a ubiquitination cascade that activates NIK-dependent alternative NF-kappaB signaling. Nat. Immunol. 2008, 9, 1364-1370. [CrossRef] [PubMed]

55. Zarnegar, B.J.; Wang, Y.; Mahoney, D.J.; Dempsey, P.W.; Cheung, H.H.; He, J.; Shiba, T.; Yang, X.; Yeh, W.C.; Mak, T.W.; et al. Noncanonical NF-kappaB activation requires coordinated assembly of a regulatory complex of the adaptors CIAP1, CIAP2, TRAF2 and TRAF3 and the kinase nik. Nat. Immunol. 2008, 9, 1371-1378. [CrossRef] [PubMed]

56. Razani, B.; Zarnegar, B.; Ytterberg, A.J.; Shiba, T.; Dempsey, P.W.; Ware, C.F.; Loo, J.A.; Cheng, G. Negative feedback in noncanonical NF-kappaB signaling modulates NIK stability through IKKalpha-mediated phosphorylation. Sci. Signal. 2010, 3, ra41. [CrossRef] [PubMed]

57. Bonizzi, G.; Bebien, M.; Otero, D.C.; Johnson-Vroom, K.E.; Cao, Y.; Vu, D.; Jegga, A.G.; Aronow, B.J.; Ghosh, G.; Rickert, R.C.; et al. Activation of IKKalpha target genes depends on recognition of specific kappaB binding sites by RelB:P52 dimers. EMBO J. 2004, 23, 4202-4210. [CrossRef] [PubMed]

58. Fusco, A.J.; Huang, D.B.; Miller, D.; Wang, V.Y.; Vu, D.; Ghosh, G. NF-kappaB p52:ReLB heterodimer recognizes two classes of kappaB sites with two distinct modes. EMBO Rep. 2009, 10, 152-159. [CrossRef] [PubMed] 
59. Mukherjee, T.; Chatterjee, B.; Dhar, A.; Bais, S.S.; Chawla, M.; Roy, P.; George, A.; Bal, V.; Rath, S.; Basak, S. A TNF-p100 pathway subverts noncanonical NF-kappaB signaling in inflamed secondary lymphoid organs. EMBO J. 2017, 36, 3501-3516. [CrossRef] [PubMed]

60. Siggers, T.; Chang, A.B.; Teixeira, A.; Wong, D.; Williams, K.J.; Ahmed, B.; Ragoussis, J.; Udalova, I.A.; Smale, S.T.; Bulyk, M.L. Principles of dimer-specific gene regulation revealed by a comprehensive characterization of NF-kappaB family DNA binding. Nat. Immunol. 2011, 13, 95-102. [CrossRef] [PubMed]

61. Zhao, B.; Barrera, L.A.; Ersing, I.; Willox, B.; Schmidt, S.C.; Greenfeld, H.; Zhou, H.; Mollo, S.B.; Shi, T.T.; Takasaki, K.; et al. The NF-kappaB genomic landscape in lymphoblastoid B cells. Cell Rep. 2014, 8, 1595-1606. [CrossRef] [PubMed]

62. De Oliveira, K.A.; Kaergel, E.; Heinig, M.; Fontaine, J.F.; Patone, G.; Muro, E.M.; Mathas, S.; Hummel, M.; Andrade-Navarro, M.A.; Hubner, N.; et al. A roadmap of constitutive NF-kappaB activity in hodgkin lymphoma: Dominant roles of p50 and p52 revealed by genome-wide analyses. Genome Med. 2016, 8, 28. [CrossRef] [PubMed]

63. Roy, P.; Mukherjee, T.; Chatterjee, B.; Vijayaragavan, B.; Banoth, B.; Basak, S. Non-canonical nfkappab mutations reinforce pro-survival tnf response in multiple myeloma through an autoregulatory RelB:P50 NFkappaB pathway. Oncogene 2017, 36, 1417-1429. [CrossRef] [PubMed]

64. Shih, V.F.; Davis-Turak, J.; Macal, M.; Huang, J.Q.; Ponomarenko, J.; Kearns, J.D.; Yu, T.; Fagerlund, R.; Asagiri, M.; Zuniga, E.I.; et al. Control of RelB during dendritic cell activation integrates canonical and noncanonical NF-kappaB pathways. Nat. Immunol. 2012, 13, 1162-1170. [CrossRef] [PubMed]

65. Cormier, F.; Monjanel, H.; Fabre, C.; Billot, K.; Sapharikas, E.; Chereau, F.; Bordereaux, D.; Molina, T.J.; Avet-Loiseau, H.; Baud, V. Frequent engagement of RelB activation is critical for cell survival in multiple myeloma. PLoS ONE 2013, 8, e59127. [CrossRef] [PubMed]

66. Smale, S.T. Dimer-specific regulatory mechanisms within the NF-kappaB family of transcription factors. Immunol. Rev. 2012, 246, 193-204. [CrossRef] [PubMed]

67. Chapman, M.A.; Lawrence, M.S.; Keats, J.J.; Cibulskis, K.; Sougnez, C.; Schinzel, A.C.; Harview, C.L.; Brunet, J.P.; Ahmann, G.J.; Adli, M.; et al. Initial genome sequencing and analysis of multiple myeloma. Nature 2011, 471, 467-472. [CrossRef] [PubMed]

68. Walker, B.A.; Boyle, E.M.; Wardell, C.P.; Murison, A.; Begum, D.B.; Dahir, N.M.; Proszek, P.Z.; Johnson, D.C.; Kaiser, M.F.; Melchor, L.; et al. Mutational spectrum, copy number changes, and outcome: Results of a sequencing study of patients with newly diagnosed myeloma. J. Clin. Oncol. 2015, 33, 3911-3920. [CrossRef] [PubMed]

69. Chng, W.J.; Kumar, S.; Vanwier, S.; Ahmann, G.; Price-Troska, T.; Henderson, K.; Chung, T.H.; Kim, S.; Mulligan, G.; Bryant, B.; et al. Molecular dissection of hyperdiploid multiple myeloma by gene expression profiling. Cancer Res. 2007, 67, 2982-2989. [CrossRef] [PubMed]

70. Hideshima, T.; Mitsiades, C.; Tonon, G.; Richardson, P.G.; Anderson, K.C. Understanding multiple myeloma pathogenesis in the bone marrow to identify new therapeutic targets. Nat. Rev. Cancer 2007, 7, 585-598. [CrossRef] [PubMed]

71. Fairfield, H.; Falank, C.; Avery, L.; Reagan, M.R. Multiple myeloma in the marrow: Pathogenesis and treatments. Ann. N. Y. Acad. Sci. 2016, 1364, 32-51. [CrossRef] [PubMed]

72. Chauhan, D.; Uchiyama, H.; Akbarali, Y.; Urashima, M.; Yamamoto, K.; Libermann, T.A.; Anderson, K.C. Multiple myeloma cell adhesion-induced interleukin-6 expression in bone marrow stromal cells involves activation of NF-kappa B. Blood 1996, 87, 1104-1112. [PubMed]

73. Costes, V.; Portier, M.; Lu, Z.Y.; Rossi, J.F.; Bataille, R.; Klein, B. Interleukin-1 in multiple myeloma: Producer cells and their role in the control of IL-6 production. Br. J. Haematol. 1998, 103, 1152-1160. [CrossRef] [PubMed]

74. Podar, K.; Anderson, K.C. Emerging therapies targeting tumor vasculature in multiple myeloma and other hematologic and solid malignancies. Curr. Cancer Drug Targets 2011, 11, 1005-1024. [CrossRef] [PubMed]

75. Chilov, D.; Kukk, E.; Taira, S.; Jeltsch, M.; Kaukonen, J.; Palotie, A.; Joukov, V.; Alitalo, K. Genomic organization of human and mouse genes for vascular endothelial growth factor C. J. Biol. Chem. 1997, 272, 25176-25183. [CrossRef] [PubMed]

76. Mitsiades, C.S.; Mitsiades, N.; Poulaki, V.; Schlossman, R.; Akiyama, M.; Chauhan, D.; Hideshima, T.; Treon, S.P.; Munshi, N.C.; Richardson, P.G.; et al. Activation of NF-kappaB and upregulation of intracellular 
anti-apoptotic proteins via the IGF-1/AKT signaling in human multiple myeloma cells: Therapeutic implications. Oncogene 2002, 21, 5673-5683. [CrossRef] [PubMed]

77. Sprynski, A.C.; Hose, D.; Caillot, L.; Reme, T.; Shaughnessy, J.D., Jr.; Barlogie, B.; Seckinger, A.; Moreaux, J.; Hundemer, M.; Jourdan, M.; et al. The role of IGF-1 as a major growth factor for myeloma cell lines and the prognostic relevance of the expression of its receptor. Blood 2009, 113, 4614-4626. [CrossRef] [PubMed]

78. Musolino, C.; Allegra, A.; Innao, V.; Allegra, A.G.; Pioggia, G.; Gangemi, S. Inflammatory and anti-inflammatory equilibrium, proliferative and antiproliferative balance: The role of cytokines in multiple myeloma. Med. Inflamm. 2017, 2017, 1852517. [CrossRef] [PubMed]

79. Tsubaki, M.; Komai, M.; Itoh, T.; Imano, M.; Sakamoto, K.; Shimaoka, H.; Ogawa, N.; Mashimo, K.; Fujiwara, D.; Takeda, T.; et al. Inhibition of the tumour necrosis factor-alpha autocrine loop enhances the sensitivity of multiple myeloma cells to anticancer drugs. Eur. J. Cancer 2013, 49, 3708-3717. [CrossRef] [PubMed]

80. Corral, L.G.; Haslett, P.A.; Muller, G.W.; Chen, R.; Wong, L.M.; Ocampo, C.J.; Patterson, R.T.; Stirling, D.I.; Kaplan, G. Differential cytokine modulation and $\mathrm{T}$ cell activation by two distinct classes of thalidomide analogues that are potent inhibitors of TNF-alpha. J. Immunol. 1999, 163, 380-386. [PubMed]

81. Quach, H.; Ritchie, D.; Stewart, A.K.; Neeson, P.; Harrison, S.; Smyth, M.J.; Prince, H.M. Mechanism of action of immunomodulatory drugs (IMIDS) in multiple myeloma. Leukemia 2010, 24, 22-32. [CrossRef] [PubMed]

82. Moreaux, J.; Legouffe, E.; Jourdan, E.; Quittet, P.; Reme, T.; Lugagne, C.; Moine, P.; Rossi, J.F.; Klein, B.; Tarte, K. Baff and april protect myeloma cells from apoptosis induced by interleukin 6 deprivation and dexamethasone. Blood 2004, 103, 3148-3157. [CrossRef] [PubMed]

83. Hengeveld, P.J.; Kersten, M.J. B-cell activating factor in the pathophysiology of multiple myeloma: A target for therapy? Blood Cancer J. 2015, 5, e282. [CrossRef] [PubMed]

84. Carpenter, R.O.; Evbuomwan, M.O.; Pittaluga, S.; Rose, J.J.; Raffeld, M.; Yang, S.; Gress, R.E.; Hakim, F.T.; Kochenderfer, J.N. B-cell maturation antigen is a promising target for adoptive T-cell therapy of multiple myeloma. Clin. Cancer Res. 2013, 19, 2048-2060. [CrossRef] [PubMed]

85. Schmiedel, B.J.; Scheible, C.A.; Nuebling, T.; Kopp, H.G.; Wirths, S.; Azuma, M.; Schneider, P.; Jung, G.; Grosse-Hovest, L.; Salih, H.R. Rankl expression, function, and therapeutic targeting in multiple myeloma and chronic lymphocytic leukemia. Cancer Res. 2013, 73, 683-694. [CrossRef] [PubMed]

86. Landowski, T.H.; Olashaw, N.E.; Agrawal, D.; Dalton, W.S. Cell adhesion-mediated drug resistance (CAM-DR) is associated with activation of NF-kappa B (RelB/p50) in myeloma cells. Oncogene 2003, 22, 2417-2421. [CrossRef] [PubMed]

87. Roccaro, A.M.; Sacco, A.; Purschke, W.G.; Moschetta, M.; Buchner, K.; Maasch, C.; Zboralski, D.; Zollner, S.; Vonhoff, S.; Mishima, Y.; et al. SDF-1 inhibition targets the bone marrow niche for cancer therapy. Cell Rep. 2014, 9, 118-128. [CrossRef] [PubMed]

88. Thu, Y.M.; Richmond, A. NF-kappaB inducing kinase: A key regulator in the immune system and in cancer. Cytokine Growth Factor Rev. 2010, 21, 213-226. [CrossRef] [PubMed]

89. Shih, V.F.; Tsui, R.; Caldwell, A.; Hoffmann, A. A single nfkappab system for both canonical and non-canonical signaling. Cell Res. 2011, 21, 86-102. [CrossRef] [PubMed]

90. Basak, S.; Kim, H.; Kearns, J.D.; Tergaonkar, V.; O’Dea, E.; Werner, S.L.; Benedict, C.A.; Ware, C.F.; Ghosh, G.; Verma, I.M.; et al. A fourth IKappaB protein within the NF-kappaB signaling module. Cell 2007, 128, 369-381. [CrossRef] [PubMed]

91. Shih, V.F.; Kearns, J.D.; Basak, S.; Savinova, O.V.; Ghosh, G.; Hoffmann, A. Kinetic control of negative feedback regulators of NF-kappaB/RelA determines their pathogen- and cytokine-receptor signaling specificity. Proc. Natl. Acad. Sci. USA 2009, 106, 9619-9624. [CrossRef] [PubMed]

92. Almaden, J.V.; Tsui, R.; Liu, Y.C.; Birnbaum, H.; Shokhirev, M.N.; Ngo, K.A.; Davis-Turak, J.C.; Otero, D.; Basak, S.; Rickert, R.C.; et al. A pathway switch directs baff signaling to distinct NFkappaB transcription factors in maturing and proliferating B cells. Cell Rep. 2014, 9, 2098-2111. [CrossRef] [PubMed]

93. Zarnegar, B.; Yamazaki, S.; He, J.Q.; Cheng, G. Control of canonical NF-kappaB activation through the nik-ikk complex pathway. Proc. Natl. Acad. Sci. USA 2008, 105, 3503-3508. [CrossRef] [PubMed]

94. Demchenko, Y.N.; Glebov, O.K.; Zingone, A.; Keats, J.J.; Bergsagel, P.L.; Kuehl, W.M. Classical and/or alternative NF-kappaB pathway activation in multiple myeloma. Blood 2010, 115, 3541-3552. [CrossRef] [PubMed] 
95. Hideshima, T.; Chauhan, D.; Kiziltepe, T.; Ikeda, H.; Okawa, Y.; Podar, K.; Raje, N.; Protopopov, A.; Munshi, N.C.; Richardson, P.G.; et al. Biologic sequelae of I\{kappa\}B kinase (IKK) inhibition in multiple myeloma: Therapeutic implications. Blood 2009, 113, 5228-5236. [CrossRef] [PubMed]

96. Fabre, C.; Mimura, N.; Bobb, K.; Kong, S.Y.; Gorgun, G.; Cirstea, D.; Hu, Y.; Minami, J.; Ohguchi, H.; Zhang, J.; et al. Dual inhibition of canonical and noncanonical NF-kappaB pathways demonstrates significant antitumor activities in multiple myeloma. Clin. Cancer Res. 2012, 18, 4669-4681. [CrossRef] [PubMed]

97. Derudder, E.; Dejardin, E.; Pritchard, L.L.; Green, D.R.; Korner, M.; Baud, V. RelB/p50 dimers are differentially regulated by tumor necrosis factor-alpha and lymphotoxin-beta receptor activation: Critical roles for p100. J. Biol. Chem. 2003, 278, 23278-23284. [CrossRef] [PubMed]

98. Basak, S.; Shih, V.F.; Hoffmann, A. Generation and activation of multiple dimeric transcription factors within the NF-kappaB signaling system. Mol. Cell Biol. 2008, 28, 3139-3150. [CrossRef] [PubMed]

99. Busino, L.; Millman, S.E.; Scotto, L.; Kyratsous, C.A.; Basrur, V.; O'Connor, O.; Hoffmann, A.; Elenitoba-Johnson, K.S.; Pagano, M. Fbxw7alpha- and GSK3-mediated degradation of 100 is a pro-survival mechanism in multiple myeloma. Nat. Cell Biol. 2012, 14, 375-385. [CrossRef] [PubMed]

100. Mineva, N.D.; Rothstein, T.L.; Meyers, J.A.; Lerner, A.; Sonenshein, G.E. CD40 ligand-mediated activation of the de novo RelB NF-kappaB synthesis pathway in transformed B cells promotes rescue from apoptosis. J. Biol. Chem. 2007, 282, 17475-17485. [CrossRef] [PubMed]

101. Wang, X.; Belguise, K.; Kersual, N.; Kirsch, K.H.; Mineva, N.D.; Galtier, F.; Chalbos, D.; Sonenshein, G.E. Oestrogen signalling inhibits invasive phenotype by repressing RelB and its target BCL2. Nat. Cell Biol. 2007, 9, 470-478. [CrossRef] [PubMed]

102. Dejardin, E.; Droin, N.M.; Delhase, M.; Haas, E.; Cao, Y.; Makris, C.; Li, Z.W.; Karin, M.; Ware, C.F.; Green, D.R. The lymphotoxin-beta receptor induces different patterns of gene expression via two NF-kappaB pathways. Immunity 2002, 17, 525-535. [CrossRef]

103. Stadanlick, J.E.; Kaileh, M.; Karnell, F.G.; Scholz, J.L.; Miller, J.P.; Quinn, W.J., 3rd; Brezski, R.J.; Treml, L.S.; Jordan, K.A.; Monroe, J.G.; et al. Tonic b cell antigen receptor signals supply an NF-kappaB substrate for prosurvival blys signaling. Nat. Immunol. 2008, 9, 1379-1387. [CrossRef] [PubMed]

104. Yilmaz, Z.B.; Kofahl, B.; Beaudette, P.; Baum, K.; Ipenberg, I.; Weih, F.; Wolf, J.; Dittmar, G.; Scheidereit, C. Quantitative dissection and modeling of the nf-kappab p100-p105 module reveals interdependent precursor proteolysis. Cell Rep. 2014, 9, 1756-1769. [CrossRef] [PubMed]

105. Tai, Y.T.; Li, X.; Tong, X.; Santos, D.; Otsuki, T.; Catley, L.; Tournilhac, O.; Podar, K.; Hideshima, T.; Schlossman, R.; et al. Human anti-CD40 antagonist antibody triggers significant antitumor activity against human multiple myeloma. Cancer Res. 2005, 65, 5898-5906. [CrossRef] [PubMed]

106. Zarnegar, B.; He, J.Q.; Oganesyan, G.; Hoffmann, A.; Baltimore, D.; Cheng, G. Unique CD40-mediated biological program in B cell activation requires both type 1 and type 2 NF-kappaB activation pathways. Proc. Natl. Acad. Sci. USA 2004, 101, 8108-8113. [CrossRef] [PubMed]

107. Bensinger, W.; Maziarz, R.T.; Jagannath, S.; Spencer, A.; Durrant, S.; Becker, P.S.; Ewald, B.; Bilic, S.; Rediske, J.; Baeck, J.; et al. A phase 1 study of lucatumumab, a fully human anti-CD40 antagonist monoclonal antibody administered intravenously to patients with relapsed or refractory multiple myeloma. Br. J. Haematol. 2012, 159, 58-66. [CrossRef] [PubMed]

108. Sati, H.I.; Apperley, J.F.; Greaves, M.; Lawry, J.; Gooding, R.; Russell, R.G.; Croucher, P.I. Interleukin-6 is expressed by plasma cells from patients with multiple myeloma and monoclonal gammopathy of undetermined significance. Br. J. Haematol. 1998, 101, 287-295. [CrossRef] [PubMed]

109. Cozzolino, F.; Torcia, M.; Aldinucci, D.; Rubartelli, A.; Miliani, A.; Shaw, A.R.; Lansdorp, P.M.; Di Guglielmo, R. Production of interleukin-1 by bone marrow myeloma cells. Blood 1989, 74, 380-387. [PubMed]

110. Frassanito, M.A.; Cusmai, A.; Iodice, G.; Dammacco, F. Autocrine interleukin-6 production and highly malignant multiple myeloma: Relation with resistance to drug-induced apoptosis. Blood 2001, 97, 483-489. [CrossRef] [PubMed]

111. Tai, Y.T.; Li, X.F.; Breitkreutz, I.; Song, W.; Neri, P.; Catley, L.; Podar, K.; Hideshima, T.; Chauhan, D.; Raje, N.; et al. Role of B-cell-activating factor in adhesion and growth of human multiple myeloma cells in the bone marrow microenvironment. Cancer Res. 2006, 66, 6675-6682. [CrossRef] [PubMed] 
112. Tornatore, L.; Sandomenico, A.; Raimondo, D.; Low, C.; Rocci, A.; Tralau-Stewart, C.; Capece, D.; D'Andrea, D.; Bua, M.; Boyle, E.; et al. Cancer-selective targeting of the NF-kappaB survival pathway with GADD45beta/MKK7 inhibitors. Cancer Cell 2014, 26, 495-508. [CrossRef] [PubMed]

113. Romashkova, J.A.; Makarov, S.S. NF-kappaB is a target of akt in anti-apoptotic PDGF signalling. Nature 1999, 401, 86-90. [CrossRef] [PubMed]

114. Toth, C.R.; Hostutler, R.F.; Baldwin, A.S., Jr.; Bender, T.P. Members of the nuclear factor kappa B family transactivate the murine c-myb gene. J. Biol. Chem. 1995, 270, 7661-7671. [CrossRef] [PubMed]

115. Gardam, S.; Beyaert, R. The kinase NIK as a therapeutic target in multiple myeloma. Expert Opin. Ther. Targets 2011, 15, 207-218. [CrossRef] [PubMed]

116. Mailankody, S.; Kazandjian, D.; Korde, N.; Roschewski, M.; Manasanch, E.; Bhutani, M.; Tageja, N.; Kwok, M.; Zhang, Y.; Zingone, A.; et al. Baseline mutational patterns and sustained MRD negativity in patients with high-risk smoldering myeloma. Blood Adv. 2017, 1, 1911-1918. [CrossRef] [PubMed]

117. Mikulasova, A.; Wardell, C.P.; Murison, A.; Boyle, E.M.; Jackson, G.H.; Smetana, J.; Kufova, Z.; Pour, L.; Sandecka, V.; Almasi, M.; et al. The spectrum of somatic mutations in monoclonal gammopathy of undetermined significance indicates a less complex genomic landscape than that in multiple myeloma. Haematologica 2017, 102, 1617-1625. [CrossRef] [PubMed]

(c) 2018 by the authors. Licensee MDPI, Basel, Switzerland. This article is an open access article distributed under the terms and conditions of the Creative Commons Attribution (CC BY) license (http:/ / creativecommons.org/licenses/by/4.0/). 